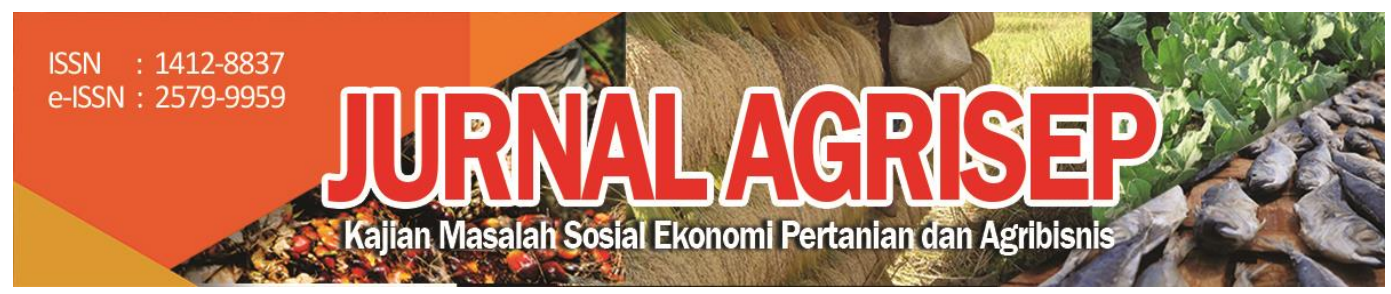

DOI: 10.31186/jagrisep.20.1.141-156

\title{
TEKNOLOGI SISTEM BOSTER PADA BUDIDAYA LELE: DALAM PERSPEKTIF KOMUNIKASI DI DESA JAMBEWANGI KECAMATAN SEMPU KABUPATEN BANYUWANGI
}

\author{
Booster System Technology on Catfish Cultivation: In Term of \\ Communication Perspective in Jambewangi Village, Sempu Sub District, \\ Banyuwangi District \\ Lenny Widjayanthi ${ }^{\bigotimes_{1}}$ ); Zulfia Asdi Mauladani ${ }^{2}$ ) \\ 1) Program Studi Penyuluhan Pertanian, Fakultas Pertanian Universitas \\ Jember \\ 2) Program Studi Agribisnis Fakultas Pertanian Universitas Jember \\ Email: lenny.faperta@unej.ac.id
}

\begin{abstract}
This purposes of the research were explaining the process of communication that occurred in the process of the adoption of a Booster system innovation in catfish farming. Determination of research area is done purposively in Jambewangi Village, Sempu Subdistrict, Banyuwamgi District. The subject of the research is chosen purposively. Data collection was carried out for 5 months from October 2018-March 2019 using indepth interviews, observations and documents. The research informants consisted of 3 people who adopted the booster system and 1 person who decided not to adopt. Data analysis used Miles and Huberman.

The results of the research showed that the innovation adoption process was carried out through some stages, namely knowledge, persuasion, decision, implementation and confirmation. The community has different knowledge about the booster system, the booster system has been known since 2014, to improve knowledge and skills in the booster system, catfish farmers attend trainings held in various cities. It took between 3-6 months to decide to adopt, the informant refused to adopt the booster system after knowing that the pond model used was different from the pond in the previous system culture. The informants did not implement a complete booster system because the multivitamins were given as needed. Catfish farmers decided to continue cultivating catfish with a booster system for the following year. Each stage that is passed uses interpersonal
\end{abstract}


communication channels to exchange messages. The speed at which an innovation was adopted was influenced by the nature of the innovation, namely relative advantage, compatibility, complexity, triability and observability.

Keywords: adoption of innovations, booster system, characteristis of innovation, communication

\section{ABSTRAK}

Tujuan penelitian adalah menjelaskan proses komunikasi yang terjadi dalam proses adopsi inovasi sistem boster pada budidaya lele di Desa Jambewangi Kecamatan Sempu Kabupaten Banyuwangi. Lokasi penelitian tersebut ditentukan menggunakan purposive method karena Desa Jambewangi merupakan salah satu daerah yang mengembangkan sistem boster karena banyak masyarakat setempat yang melakukan budidaya lele. Pengumpulan data dilakukan selama 5 bulan mulai bulan Oktober 2018Maret 2019 dengan menggunakan wawancara mendalam, observasi dan dokumen. Informan penelitian terdiri dari 3 orang yang mengadopsi sistem boster dan 1 orang yang memutuskan untuk tidak mengadopsi. Analisis data menggunakan Miles dan Huberman

Hasil kajian lapang menunjukkan bahwa proses adopsi inovasi dilakukan melalui beberapa tahap yaitu pengetahuan, persuasi, keputusan, implementasi dan konfirmasi. Pengetahuan masyarakat tentang sistem boster berbeda, sistem boster diketahui sejak tahun 2014, pembudidaya mengikuti pelatihan-pelatihan yang diselenggarakan di berbagai kota untuk meningkatkan pengetahuan dan ketrampilan budidaya lele sistem boster. Diperlukan waktu antara 3-6 bulan untuk memutuskan mengadopsi, informan menolak mengadopsi sistem boster setelah mengetahui bahwa model kolam yang digunakan berbeda dengan kolam pada budidaya sistem sebelumnya. Informan tidak mengimplementasikan budidaya sistem boster sesuai SOP karena multivitamin diberikan sesuai kebutuhan. Pembudidaya sistem boster memutuskan untuk tetap melakukan budidaya lele dengan sistem boster sesuai dengan perkembangan. Setiap tahap yang dilalui menggunakan saluran komunikasi interpesonal untuk bertukar pesan. Kecepatan suatu inovasi untuk diadopsi dipengaruhi oleh sifat inovasi tersebut yaitu keuntungan relatif, kompatibilitas, kompleksitas, triabilitas dan observabilitas.

Kata Kunci: Adopsi inovasi, system boster, karakteristik inovasi, komunikasi.

\section{PENDAHULUAN}

Sektor perikanan mengalami kemajuan yang cukup pesat karena masyarakat banyak yang tertarik untuk melakukan usaha perikanan budidaya atau perikanan darat. Usaha perikanan budidaya adalah alternatif yang dapat dijadikan sebagai usaha untuk peningkatan kegiatan perekonomian di Indonesia (Sutrisno, 2007) dan menjadi komoditas unggulan (Adam, 2012). Perikanan budidaya dinilai memberikan peranan penting untuk perekonomian Indonesia karena menjadi penyedia lapangan kerja, meningkatkan pendapatan, memenuhi 
kebutuhan gizi masyarakat (Nasrudin, 2010), penyedia bahan baku sektor agroindustri, penyumbang devisa negara dari hasil ekspor. Usaha perikanan budidaya saat ini semakin berkembang dan bervariasi. Keragaman jenis komoditas mulai meningkat dan teknologi budidaya juga semakin berkembang. Jenis ikan untuk budidaya yang dilakukan merupakan ikan yang sudah cukup dikenal dan digemari masyarakat sehingga ikan tersebut relatif dibutuhkan dan laku di pasaran (Saparinto, 2013). Selain itu, menurut Fauzi, A (2005), sumber daya perikanan sebagai aset negara yang dapat memberikan sumbangan berarti bagi kesejahteraan hidup suatu bangsa (Wealth of nation).

Usaha budidaya lele memberikan prospek bisnis yang menjanjikan karena tingginya permintaan masyarakat terhadap lele untuk kebutuhan dan konsumsi. Ikan merupakan sumber protein hewani dan sebagai bahan makanan yang murah dan mudah didapatkan serta dibudidayakan (Susanto, 2002). Selain itu, lele telah dibudidayakan secara komersial oleh masyarakat Indonesia, terutama di pulau Jawa (Hadi, 2015).

Usaha lele merupakan prospek bisnis yang sangat menjanjikan karena tingginya permintaan masyarakat terhadap lele untuk memenuhi kebutuhan konsumsi keluarga dan menu di warung makan maupun lesehan. Konsumsi ikan per orang pada tahun 2008 rata-rata $28 \mathrm{~kg} /$ tahun dan pada tahun 2010 dan 2030 diperkirakan naik menjadi $30 \mathrm{~kg} / \mathrm{tahun}$ dan $45 \mathrm{~kg} /$ tahun (Putri 2014). Tingginya permintaan ikan lele saat ini membuat para pembudidaya lele melakukan berbagai inovasi untuk mengoptimalkan usaha dan produksi lele.

Inovasi merupakan suatu gagasan, metode, atau objek yang dianggap sebagai sesuatu yang baru (Ban dan Hawkins, 1999). Salah satu inovasi dalam budidaya lele adalah sistem boster. Sistem boster merupakan salah satu budidaya lele yang terkategori super intensif yaitu dengan menerapkan teknologi padat tebar tinggi, yaitu lebih dari 500-1000 ekor per $\mathrm{m}^{2}$ dan menggunakan produk suplemen boster untuk meningkatkan kualitas dan kuantitas produksi lele. Sistem boster menggunakan air bersih dalam kegiatan budidayanya dan pemberian pellet sebagai makanan lele (Fish Boster Center, 2017).

Sistem boster awalnya hanya dilakukan oleh seorang pembudidaya karena menganggap bahwa system boster dapat memberikan keuntungan lebih baik dibandingkan dengan system konvensional, dan pada saat ini, telah diaplikasikan oleh beberapa pembudidaya lele. Menurut Roger (1983), proses di mana suatu inovasi dikomunikasikan melalui saluran tertentu dari waktu ke waktu di antara anggota sistem sosial disebut sebagai difusi. Proses komunikasi dalam difusi inovasi mengharuskan adanya (1) inovasi, (2) individu atau unit adopsi lain yang memiliki pengetahuan atau pengalaman menggunakan inovasi, (3) individu lain atau unit lain yang belum memiliki pengetahuan tentang suatu inovasi, dan (4) saluran komunikasi yang menghubungkan dan mempertemukan dua unit. 
Proses pengambilan keputusan inovasi adalah merupakan proses individu yang beralih dari pengetahuan awal tentang inovasi, membentuk sikap pada inovasi, keputusan mengadopsi atau menolak, mengimplementasi ide baru, dan mengonfirmasi keputusan ini. Persuasi seseorang terhadap suatu inovasi dipengaruhi oleh sifat-sifat inovasi, keuntungan relatif, kompatibilitas, kompleksitas, triabilitas, dan observabilitas (Setiawati, 2016), (Mardikanto, 1993), (Hubeis, 2017). Tujuan penelitian untuk menjelaskan proses komunikasi dalam adopsi inovasi sistem boster pada budidaya lele di Desa Jambewangi Kecamatan Sempu Kabupaten Banyuwangi.

\section{METODE PENELITIAN}

Daerah penelitian dipilihs ecara secara sengaja (purposive method) di Desa Jambewangi Kecamatan Sempu Kabupaten Banyuwangi. Informan penelitian ditentukan dengan purposive sampling pada 3 orang pembudidaya lele yang mengadopsi dan 1 orang pembudidaya lele yang menolak mengadopsi inovasi sistem boster. Data diperoleh dari wawancara mendalam, observasi dan studi dokumen. Metode Miles dan Huberman digunakan untuk menganalisis data yaitu pengumpulan data (data collection), reduksi data (data reduction), penyajian data (data display) serta penarikan dan pengujian kesimpulan (drawing and verifying conclusions) (Miles and Huberman, 2014), (Sugiyono, 2015), (Bungin, 2012), (Yusuf, 2014) yang didasarkan pada variabel-variabel pembentuk keputusan adopsi yaitu pengetahuan terhadap system boster; persuasi terhadap inovasi; sifat-sifat inovasi yaitu berupa : keuntungan relatif, kompabilitas, kompleksitas, triabilitas dan observabilitas; keputusan setelah mengetahui sistem boster; implementasi sistem booster dalam budidaya ikan lele dan konfirmasi tentang keputusan untuk terus menggunakan sistem boster pada budidaya ikan lele. Kesemua variabel tersebut ditanyakan berdasarkan $5 \mathrm{~W}$ dan $1 \mathrm{H}$.

Pertanyaan-pertanyaan diberikan kepada informan dengan mengacu pada variabel pembentuk inovasi dengan berpedoman pada $5 \mathrm{~W}$ dan $1 \mathrm{H}$ seperti: siapa yang menginformasikan sistem boster, kemudahan informasi untuk dipahami, bagaimana komunikasi yang dilakukan, darimana mengetahui sistem boster, ketertarikan informan terhadap sistem boster, sejak kapan mengetahui sistem boster, apa reaksi setelah tahu sistem tersebut, keuntungan relatif berhubungan dengan keunggulan sistem boster dari tehnik budidaya yang lain, kompabilitas dilakukan dengan mengevaluasi bagaimana kesesuaian sistem boster terhadap kondisi dan kharakteristik setempat, kompleksitas mengacu pada kemudahan dalam mengaplikasikan sistem boster, triabilitas dievaluasi dengan kemudahan penggunaan sistem boster diaplikasikan oleh pembudidaya dan observabilitas mengacu pada perkembangan lele saat menggunakan sistem boster. Keputusan terhadap inovasi sistem boster dilakukan dengan menanyakan bagaimana sikap informan setelah mengetahui sistem boster, alasan untuk mengadopsi dan tidak 
mengadopsi, serta adakah pengaruh pihak luar terhadap keputusan mengadopsi. Implementasi sistem boster di evaluasi dari jawaban informan terhadap penerapan sistem boster berdasarkan SOP budidaya lele sistem boster, alasan menerapkan sistem boster. Sedangkan konfirmasi dilakukan dengan menanyakan kepada informan tentang meneruskan atau menghentikan penggunaan sistem boster untuk budidaya lele selanjutnya.

\section{HASIL DAN PEMBAHASAN}

\section{Pengetahuan Pembudidaya Lele terhadap Inovasi Sistem Boster dalam Budidaya Lele}

Tahap pengetahuan ini menjadi sangat penting karena pembudidaya lele mendapatkan informasi mengenai sistem boster dan menjadi bahan pertimbangan pengambilan keputusan dalam mengadopsi inovasi atau menolak inovasi tersebut. Menurut Notoatmodjo (2005), pengetahuan adalah hasil penginderaan manusia atau hasil tahu seseorang terhadap objek melalui indera yang dimilikinya. Menurut Frappaolo (2003), pengetahuan merupakan tindakan dalam merespon kondisi-kondisi lingkungan dan meransang tindakan suatu kegiatan yang digunakan dalam lingkungan yang tidak berkesesuaian. Pengetahuan (knowledge) adalah awal dari proses pengambilan keputusan suatu inovasi dengan pengetahuan umum yang dimulai ketika unit individu (atau pembuatan keputusan lain) mengetahui adanya inovasi dan memperoleh pemahaman terhadap fungsi dari inovasi tersebut (Rogers, 1983).

Waktu penginderaan menghasilkan pengetahuan yang dipengaruhi intensitas perhatian dan persepsi terhadap objek. Sebagian besar pengetahuan seseorang diperoleh melalui indera pendengaran (telinga) dan indera penglihatan. Pengetahuan mengenai inovasi sistem boster yang dipahami oleh masyarakat berbeda-beda. Sebagian masyarakat mengetahui bahwa boster adalah nama perusahaan yang memproduksi suplemen lele, sedangkan sebagian masyarakat yang lain memahami bahwa sistem boster merupakan cara budidaya lele dengan melakukan manajemen terhadap air, pakan dan kesehatan. Inovasi sistem boster mulai dikenal sejak tahun 2014. Keunggulan sistem boster dapat diketahui dari pengaturan manajemen air dengan menggunakan sistem kolam central drain, manajemen kesehatan dengan memberikan mutivitamin atau suplemen Boster pada lele, serta manajemen pakan yang mengharuskan pembudidaya lele untuk memberikan pakan pellet pada lele. Pembesaran ikan lele dengan sistem boster memiliki 4 faktor agar bisa berhasil diterapkan, yaitu: daya dukung kolam, manajemen air, manajemen pakan, dan manajemen kesehatan ikan (Bachtiar Arifin, dkk, 2017)

Manajemen air yang diterapkan oleh sistem boster mengharuskan penggunaan air bersih sehingga persediaan air bersih harus selalu terpenuhi, hal ini menyebabkan pembudidaya lele yang mengadopsi sitem boster harus 
membuat sumur biasa atau sumur bor untuk memenuhi kebutuhan air bersih tersebut.

\section{Persuasi Pembudidaya Lele terhadap Inovasi Sistem Boster dalam Budidaya Lele}

Persuasi (persuasion) terjadi saat seorang individu (membentuk sikap yang baik atau tidak baik terhadap inovasi. Tipe utama pemikiran dalam proses persuasi adalah afektif atau perasaan, dan individu akan menentukan sikap ketika individu tersebut tahu tentang ide baru itu (Rogers, 1983).

Sistem booster sudah diketahui oleh informan sejak awal 2014, tetapi perlu waktu sekitar 3-6 bulan untuk mengadopsinya, hal ini dilakukan karena informan belum mengetahui manfaat budidaya dengan menggunakan sistem boster. Untuk menambah pengetahuan dan ketrampilan dalam budidaya sistem boster, Informan mengikuti pelatihan-pelatihan di beberapa wilayah misal Purbalingga, Jombang, Kediri, Nganjuk, Sidoarjo, Probolinggo dan Gresik. Pelatihan dilakukan secara intensif, sehingga dapat diketahui keunggulan dan kelemahan pada setiap sistem budidaya lele yang dipelajari. Pengetahuan tersebut yang akan dijadikan landasan untuk memilih sebuah inovasi untuk diadopsi atau tidak.

Budidaya lele dengan sistem boster memiliki perbedaan dengan sistem budidaya lele yang lainnya. Perbedaannya adalah pengaturan konstruksi kolam yang berdampak pada sistem pembuangan kotoran dan amoniaknya. Sistem boster fokus pada manajemen air dengan menjaga air dan kolam selalu dalam kondisi bersih, karena sistem pembuangan dibuat pada bagian tengah kolam dengan bagian tengah dikonstruksi lebih dalam disebut central drain (membuat cekungan persegi di bagian tengah kolam), sehingga kotoran-kotoran terlokasi di tengah sehingga memudahkan untuk pembuangan kotoran dan kondisi air kolam tetap bersih. Manajemen kesehatan juga mendapat perhatian penuh dengan selalu memperhatikan asupan nutrisi lele, yaitu dengan memberikan tambahan mutivitamin atau suplemen pada pakan.

Masyarakat yang masih memiliki keraguan terhadap inovasi sistem boster akan diajak untuk mengunjungi PT Boster sehingga dapat mengetahui secara langsung mengenai cara kerja dan keunggulan sistem boster dari innovator. Hal ini sesuai denga teori Rogers (1983) yang menyatakan bahwa saluran inter personal relatif lebih penting pada tahap persuasi karena dapat mempengaruhi individu untuk merubah sikap, hal ini terbukti dengan masyarakat yang masih memiliki keraguan dapat lebih yakin untuk tertarik dengan sistem boster. Sikap tidak tertarik terhadap Inovasi sistem boster disebabkan karena informan menyatakan bahwa sistem boster membutuhkan biaya yang besar dan hasil yang kurang menjanjikan, sedangkan informan yang tertarik dengan sistem boster menyatakan bahwa sistem boster memudahkan pekerjaan dengan model 
kolam yang memiliki cekungan di tengah dan air selalu bersih sehingga lele sehat dan memiliki pertumbuhan yang cepat.

Menurut Hanafi (1987), terdapat dua tingkatan sikap yaitu sikap khusus terhadap inovasi dan sikap umum terhadap perubahan. Sikap khusus terhadap inovasi adalah berkenaan atau tidaknya seseorang, percaya atau tidaknya seseorang terhadap kegunaan inovasi untuk dirinya sendiri. Sikap tertarik yang ditunjukkan oleh masyarakat terhadap inovasi sistem boster karena melihat berbagai keunggulan yang dimiliki, bahkan sistem boster dinilai sebagai sistem budidaya lele terbaik dibandingkan dengan sistem budidaya lele yang lain. Sikap yang ditunjukkan oleh masyarakat tersebut dipengaruhi oleh sifat-sifat inovasi sebagaimana berikut ini.

\section{Keuntungan relatif (relative advantages)}

Keuntungan relatif merupakan keunggulan atau keuntungan yang diperoleh dari penggunaan suatu inovasi tertentu dan memberikan dampak lebih baik dibandingkan dengan cara-cara sebelumnya. Soekartawi (1988), keuntungan relatif (Relative advantage) adalah sejauh mana teknologi baru memberikan keuntungan lebih dari pada teknologi sebelumnya secara ekonomi maupun social (Lori L. Moore, 2012).

Keuntungan relatif dapat diukur dari segi ekonomis, tetapi faktor kenyamanan dan kepuasan juga merupakan komponen penting. Keuntungan relatif tidak dilihat dari banyaknya keuntungan yang objektif dari suatu inovasi, namun dilihat secara subjektif dari pihak individu yang merasa inovasi tersebut menguntungkan (Rogers, 1983).

Keuntungan relatif dalam budidaya system boster adalah dari segi kuantitas dan kualitas produksi lele, karena memakai bahan pakan yang aman dan tidak memakai bahan pakan campuran lain selain pellet. Penggunaan multivitamin dan suplemen boster semakin mempercepat pertumbuhan lele dan meminimalisir terserangnya penyakit karena kebersihan air sangat terjaga. Pengaturan pergantian air dan bentuk konstruksi kolam dengan sistem central drain semakin memudahkan pekerjaan para pembudidaya lele. Sistem boster tidak memperbolehkan penggunaan air kotor atau air yang sudah tercemar karena akan berpengaruh terhadap kesehatan dan petumbuhan lele. Lele yang dihasilkan terasa kenyal dan tidak mudah busuk, hal ini berbeda dengan lele yang dibudidayakan dengan sistem lain yang mudah busuk dan bau setelah mati. Ciri fisik lele yang dihasilkan dengan menggunakan sistem boster juga terlihat lebih segar dan lebih cepat mengalami pertumbuhan apabila dibandingkan dengan lele yang dihasilkan dari sistem lain, hal ini disebabkan karena pemberian pakan sentrat atau pellet dan multivitamin atau suplemen khusus dari Boster. Dalam sistem boster dengan ukuran kolam 3 × 3 m mampu untuk menghasilkan $6-$ 7,5 kwintal setiap panen dengan perhitungan bahwa $1 \mathrm{~kg}$ pakan yang 
diberikan kepada ikan lele menghasilkan $1 \mathrm{~kg}$ daging ikan lele, sedangkan sistem konvensional lainnya hanya menghasilkan 2 kwintal. Jika keuntungan relatif yang dirasakan lebih besar dari suatu inovasi, maka semakin cepat inovasi diadopsi (Roger 1983).

\section{Kompatibilitas (compability)}

Kompatibilitas dinilai dari sejauh mana kesesuaian sistem boster dengan kebutuhan masyarakat, lingkungan sekitar dan fasilitas yang tersedia. Menurut Rogers (1983), kompatibilitas adalah kondisi inovasi dengan situasi klien yaitu sejauh mana suatu inovasi dianggap sesuai dengan nilai-nilai yang ada, pengalaman masa lalu dan kebutuhan pengadopsi. Kompatibilitas inovasi sistem boster cocok diterapkan karena sesuai dengan masyarakat setempat dan dinilai sangat ramah lingkungan yaitu limbah dari kotoran lele sangat bermanfaat untuk kegiatan pertanian karena dapat dijadikan pupuk dan tidak menimbulkan bau yang tidak sedap. Semakin petani merasakan kesesuaian varietas dengan kondisi setempat maka akan semakin cepat mengadopsi varietas unggul (Hutapea, 2013).

Inovasi sistem boster dapat menyesuaikan kondisi tempat. Sistem boster dapat diterapkan di lahan yang lebar maupun lahan yang sempit. Sistem boster dapat menghasilkan produksi yang optimal walaupun diterapkan pada lahan sempit dengan pengaturan air yang baik. Kebutuhan air dipenuhi dengan melakukan pembuatan sumur, baik sumur konvensional maupun sumur bor di lokasi budidaya lele dan menerapkan sistem padat tebar bibit. Sistem boster tidak menimbulkan polusi bau yaitu bau tidak sedap dan menyengat. Petani yang areal pertaniannya dialiri limbah kotoran lele sistem boster merasa sangat diuntungkan karena limbah tersebut dapat bermanfaat sebagai nutrisi tanaman.

\section{Kompleksitas (complexity)}

Rogers (1983) menyatakan bahwa kompleksitas adalah kerumitan inovasi yaitu tingkat dimana suatu inovasi dianggap sulit untuk dimengerti dan digunakan. Kerumitan inovasi memiliki hubungan negatif dengan kecepatan adopsi yaitu semakin rumit suatu inovasi, maka akan semakin lambat adopsinya. Inovasi sistem boster secara teknis mudah untuk dilakukan, namun kerumitan dirasakan saat memasuki musim penghujan yang disebabkan karena sulit mencari bibit lele pada saat musim penghujan, tetapi hal ini bisa diatasi oleh pembudidaya dengan melakukan kerjasama dengan pembibit lele. Pembudidaya lele akan mengurangi produksi saat musim penghujan untuk mengurangi risiko kerugian yang diakibatkan oleh peningkatan keasaman air kolam. Peningkatan $\mathrm{pH}$ air ini menyebabkan penyakit mudah menyerang lele sehingga mengurangi daya hidup lele, 
tetapi hal ini mudah diatasi oleh pembudidaya lele, karena ketersediaan obat obatan untuk mengatasi berbagai penyakit dan jamur sudah tersedia di pasar seperti misal anti bacteria, anti jamur, pemberian vitamin dan pakan bergizi.

Musim penghujan merupakan salah satu kendala yang rumit saat melakukan budidaya lele dengan sistem boster karena akan berpengaruh pada kegiatan budidayanya. Pembudidaya lele harus segera mengganti air kolam yang terkontaminasi dengan air hujan karena lele tidak cocok dengan air yang mengandung asam. Lele tidak diperbolehkan untuk diberi pakan saat turun hujan dan harus menunggu sampai air sudah dalam keadaan normal. Dari segi tehnis budidaya lele dengan sistem boster tidaklah rumit, karena inovasi sistem boster mudah diterapkan

\section{Triabilitas (triability)}

Triabilitas adalah dapat dicobanya suatu inovasi. Jika inovasi mudah untuk diaplikasikan maka akan lebih cepat untuk diadopsi. Percobaan awal dilakukan oleh pembudidaya lele berbeda-beda menyesuaikan dengan kolam yang tersedia. Semakin besar skala yang digunakan pembudidaya lele untuk mencoba sistem boster maka semakin besar pula risiko yang dihadapi karena modal yang dikeluarkan semakin besar. Keberanian pembudidaya lele yang mencoba sistem boster dalam skala besar karena sudah yakin terhadap keberhasilan inovasi sistem boster, meskipun mengalami kendala saat awal percobaan. Kendala yang dialami oleh pembudidaya lele saat awal melakukan sistem boster.

Percobaan pengaplikasian suatu sistem budidaya baru pada sistem boster dilakukan minimal 3 kali panen untuk memastikan keberhasilan inovasi tersebut. Hasil produksi yang stabil dan sesuai target yang diperoleh dari beberapa kali percobaan tersebut menjadi salah satu alasan bagi pembudidaya lele untuk mengadopsi sistem boster. Percobaan dilakukan agar semakin yakin dengan inovasi tersebut sebelum mengambil keputusan untuk mengadopsi

Menuru Roger (1983), ide baru yang dapat dicoba lebih cepat diadopsi daripada inovasi yang tidak dapat dicoba. Inovasi yang dapat dicoba memperkecil risiko bagi adopter.

\section{Observabilitas (observability)}

Inovasi yang terlihat bentuknya mudah dikomunikasikan kepada orang (Rogers, 1983). Masyarakat akan semakin yakin untuk mengambil keputusan mengadopsi atau tidak mengadopsi setelah melihat hasil yang diperoleh dari pengaplikasian sistem boster. Sistem boster memiliki ciri yang dapat dilihat secara nyata, seperti struktur kolam yang berbeda dengan cara budidaya lele yang lain serta kualitas dan kuantitas lele yang 
dihasilkan. Hal ini semakin memperkuat keyakinan masyarakat terhadap inovasi sistem boster. Konsumen akhir juga ada yang memahami tentang perbedaan kualitas lele yang dihasilkan dari sistem boster sehingga ada beberapa konsumen yang mau mengkonsumsi lele yang diberi pakan pellet saja. Konsumen dapat mengetahui bahwa lele tersebut diberi pakan pellet atau lainnya dilihat dari warna lele dan daging lele. Lele yang dibudidayakan dengan sistem boster terlihat lebih segar dengan daging yang kenyal dan tidak mudah busuk. Lele yang dibudidayakan dengan sistem konvensional dengan memberikan makan ayam mati berwarna pucat dan sedikit kehitaman

\section{Keputusan Pembudidaya Lele terhadap Inovasi Sistem Boster}

Keputusan (decision) terjadi jika seorang terlibat dalam kegiatan yang mengarah pada keputusan mengadopsi atau menolak inovasi (Rogers, 1983). Keputusan yang diambil oleh seseorang pasti melalui berbagai pertimbangan dan penilaian terhadap kondisi yang sedang terjadi. Keputusan yang diambil akan ditunjukkan dengan tindakan yang dilakukan, apabila pembudidaya lele memutuskan untuk mengadopsi maka akan menerapkan sistem boster sedangkan apabila menolak inovasi tersebut maka akan mencari alternatif lain.

Informan memerlukan 3-6 bulan untuk mengadopsi sistem boster dan setelah melalui berbagai kegiatan pelatihan untuk meningkatkan pengetahuan dan ketrampilan dalam melakukan budidaya lele sistem boster. Pelatihan tersebut dilakukan di beberapa kota, seperti pelatihan yang dilaksanakan di kota Purbalingga, Jombang, Kediri, Nganjuk, Sidoarjo, Probolinggo dan Gresik. Setiap ada informasi pelatihan tentang sistem boster akan langsung dihadiri oleh informan. Keputusan untuk mengadopsi inovasi sistem boster diambil setelah mengetahui cara kerja dan hasil dari inovasi sistem boster sehingga tertarik untuk mengadopsi inovasi tersebut. Keputusan untuk mengadopsi sistem boster karena melihat prospek yang bagus serta cara budidayanya lebih mudah daripada cara budidaya lele yang diterapkan sebelumnya. Sistem boster juga merupakan sistem yang kompleks dengan memperhatikan manajemen pakan dan kesehatan sehingga pengaplikasiannya lebih mudah serta mendapatkan hasil yang lebih baik.

Pembudidaya lele menolak untuk mengadopsi inovasi sistem boster pada saat setelah mengetahui bahwa sistem boster menggunakan kolam yang berbeda dengan sistem konvensional. Model kolam sistem konvensional berbeda dengan sistem boster, sehingga pembudidaya jika mengadopsi sistem boster harus merubah bentuk atau model kolam menjadi central drain. Menurut informan merubah model kolam membutuhkan biaya yang besar sehingga informan saat mengetahui sistem boster dengan model kolam central drain memutuskan untuk tidak menerapkan sistem boster, selain itu informan menyatakan bahwa dengan sistem konvensional masih memberikan keuntungan yang cukup baik. 
Menurut Hanafi (1987), dua tipe keputusan inovasi yaitu keputusan otoritas dan individual. Keputusan otoritas merupakan keputusan yang memaksa bawahan untuk menerima keputusan atasan, sedangkan keputusan individual dibedakan dalam keputusan opsional dan kolektif. Keputusan individual adalah keputusan yang dibuat oleh seseorang, tanpa melihat keputusan anggota sistem. Menurut Soekartawi (1988), sifat adopsi inovasi akan menentukan pola dalam proses pengambilan keputusan. Beberapa pola dalam pengambilan keputusan yaitu pilihan atau optional, kolektif dan kekuasaan.

Keputusan pembudidaya lele untuk mengadopsi atau tidak mengadopsi inovasi sistem boster adalah keputusan opsional yang dilakukan secara individu, dimana pengambilan keputusan tersebut dilakukan sendiri dari beberapa pilihan sistem budidaya lele dan tidak ada paksaan dari pihak manapun.

\section{Implementasi Inovasi Sistem Boster dalam Budidaya Lele}

Implementasi adalah tahap pelaksanaan inovasi sistem boster dalam budidaya lele setelah adopter melakukan pengambilan keputusan untuk mengadopsi inovasi tersebut. Sistem boster memiliki Standar Operasional Prosedur (SOP) yaitu aturan yang berkaitan tentang pengaplikasian sistem boster dengan cara kerja yang efektif dan efisien agar memperoleh hasil terbaik. Rogers (1983) mengemukakan bahwa implementasi (implementation) terjadi ketika seorang individu mengaplikasikan inovasi dalam kehidupan sehari-hari.

Saluran komunikasi pada tahap implementasi menggunakan komunikasi interpersonal yaitu komunikasi yang terjadi antara early adopter dengan pembudidaya lele yang mengadopsi inovasi sistem boster terkait dengan kegiatan budidaya lele dan pemasarannya. Komunikasi pada tahap implementasi sangat penting karena pada pengaplikasian sistem boster mungkin terjadi kendala yang harus segera tersolusi. Komunikasi interpersonal yang dilakukan pada tahap implementasi ini cukup efektif karena komunikasi yang terjalin antar adopter sistem boster dapat lebih intens.

Pengimplementasian inovasi sistem boster pada budidaya lele dilakukan sejak tahun 2014. Luas kolam yang digunakan untuk mengaplikasikan budidaya lele dengan sistem boster berbeda-beda sesuai dengan kemampuan masingmasing adopter. Kemampuan tersebut meliputi kemampuan pemenuhan terhadap kebutuhan dana atau modal, kemampuan tenaga, maupun ketersediaan lahan. Budidaya lele dengan sistem boster memiliki 3 prinsip yaitu manajemen air, manajemen pakan dan manajemen kesehatan. Manajemen air yang diterapkan oleh adopter sudah sesuai standar operasional prosedur (SOP) yaitu dengan membuat kolam sistem central drain dengan ukuran 3,5 meter x 3,5 meter dan kedalaman 1,1 meter. Sistem central drain memiliki saluran pembangan yang efektif karena langsung diarahkan pada area persawahan. Manajemen pakan juga sudah sesuai standar operasional prosedur (SOP). Pakan 
yang diberikan pada lele yang dibudidayakan dengan sistem boster adalah pellet. Tidak ada keharusan untuk menggunakan salah satu merk produk pellet, karena yang menjadi standar adalah kandungan protein pada pakan tersebut. Semakin tinggi kandungan protein pada pellet akan semakin baik untuk proses pertumbuhan lele. Pengimplementasian sistem boster tidak seluruhnya sesuai dengan standar operasional prosedur (SOP) karena ada beberapa hal yang tidak dilakukan seperti pemberian multivitamin/ suplemen yang dirasa kurang penting. Pemberian multivitamin/suplemen pada lele hanya disesuaikan dengan kebutuhan sehingga dapat menekan biaya pengeluaran.

\section{Konfirmasi Pembudidaya Lele terhadap Inovasi Sistem Boster dalam Budidaya Lele}

Proses adopsi inovasi yang paling akhir adalah tahap konfirmasi dimana adopter memberikan kepastian terhadap keputusan yang telah dibuat dan akan mengaplikasikannya secara berkelanjutan atau menghentikan adopsi inovasi sistem boster, dan hal tersebut dapat merubah keputusan awal jika ada hal yang tidak sesuai dengan harapan. Saluran komunikasi pada tahap konfirmasi adalah interpersonal yaitu terjadi antar pembudidaya lele yang tetap mengadopsi sistem boster dalam budidaya lele. Komunikasi yang terjadi antar adopter terkait dengan mencari penguatan untuk tetap mengadopsi sistem boster dengan saling berbagi informasi atau penyelesaian kendala yang dihadapi oleh setiap adopter. Semakin banyak masyarakat yang mengadopsi sistem boster maka semakin meyakinkan para adopter untuk tetap mengadopsi inovasi tersebut. Pembudidaya lele yang telah memutuskan untuk tetap mengaplikasikan sistem boster karena sudah terbiasa dan sesuai dengan cara kerja sistem tersebut. Keputusan untuk berganti pada sistem budidaya yang lain juga pasti menyebabkan pembudidaya lele harus memulai usahanya dari awal kembali. Adopter akan tetap mengaplikasikan sistem boster namun akan terus berkembang menyesuaikan kondisi dan kebutuhan, sehingga tidak memulai usaha dari awal yang dapat membutuhkan biaya yang cukup besar. Adopter inovasi sistem boster memilih untuk tetap menerapkan sistem boster karena sudah nyaman dan sangat dimudahkan. Hasil penelitian tersebut sesuai dengan teori Rogers (1983) yang mengatakan bahwa konfirmasi (confirmation) terjadi ketika seorang individu mencari penguatan untuk keputusan inovasi yang sudah dibuat.

\section{SIMPULAN DAN SARAN}

\section{Simpulan}

Proses adopsi inovasi sistem boster dalam budidaya lele di Desa Jambewangi Kecamatan Sempu Kabupaten Banyuwangi adalah sebagai berikut: a. Tahap Pengetahuan.

152 | Lenny Widjayanthi, Zulfia Asdi Mauladani;Teknologi Sistem Booster... 
Pengetahuan tentang inovasi sistem boster dipahami secara berbeda oleh masyarakat. Sebagian mengetahui boster adalah nama perusahaan yang memproduksi suplemen lele, sedangkan yang lain memahami sistem boster merupakan cara budidaya lele dengan melakukan manajemen terhadap air, pakan dan kesehatan.

b. Tahap Persuasi

Sistem booster diketahui sejak tahun 2014, informan belum mengetahui manfaat budidaya dengan menggunakan sistem boster. Untuk menambah pengetahuan dan ketrampilan dalam budidaya sistem boster, Informan mengikuti pelatihan-pelatihan di Purbalingga, Jombang, Kediri, Nganjuk, Sidoarjo, Probolinggo dan Gresik. Budidaya lele sistem boster berbeda dengan sistem budidaya lele konvensional lainnya, seperti: model kolam yang digunakan adalah central drain, air diganti secar periodik, penggunaan pakan pellet dan memberikan tambahan multivitamin atau suplemen pada pakan. Kecepatan inovasi sistem boster untuk dipengaruhi oleh sifat-sifat inovasi yaitu:

1. Keuntungan relatif dalam budidaya system boster adalah dari segi kuantitas dan kualitas produksi lele. Pengaturan pergantian air dan bentuk konstruksi kolam dengan sistem central drain memudahkan pekerjaan para pembudidaya lele. Lele yang dihasilkan terasa kenyal dan tidak mudah, terlihat lebih segar dan lebih cepat mengalami pertumbuhan dengan hasil produksi yang maksimal.

2. Kompatibilitas (compability). Inovasi sistem boster cocok diterapkan karena sesuai dengan masyarakat setempat dan dinilai sangat ramah lingkungan yaitu limbah dari kotoran lele sangat bermanfaat untuk kegiatan pertanian karena bisa dijadikan pupuk dan tidak menimbulkan bau yang tidak ditimbulkan.

3. Kompleksitas (complexity). Inovasi sistem boster secara teknis mudah untuk dilakukan, kerumitan dirasakan saat memasuki musim penghujan yang disebabkan karena sulit mencari bibit lele tetapi hal ini bisa diatasi oleh pembudidaya dengan melakukan kerjasama dengan pembibit lele. Pembudidaya lele harus segera mengganti air kolam yang terkontaminasi dengan air hujan karena lele tidak cocok dengan air yang mengandung asam

4. Triabilitas (triability). Percobaan pengaplikasian sistem boster dilakukan minimal 3 kali panen untuk memastikan keberhasilan inovasi tersebut. Hasil produksi yang stabil dan sesuai target yang diperoleh dari beberapa kali percobaan menjadi salah satu alasan bagi pembudidaya lele untuk mengadopsi sistem boster.

5. Observabilitas (observability). Sistem boster memiliki ciri yang dapat dilihat secara nyata, seperti struktur kolam, kualitas dan kuantitas lele 
yang dihasilkan, seperti lele lebih segar dengan daging yang kenyal dan tidak mudah busuk.

c. Tahap Keputusan

Informan memerlukan 3-6 bulan untuk memutuskan mengadopsi sistem boster. Keputusan diambil setelah mengetahui cara kerja dan hasil dari inovasi sistem boster dan prospek yang bagus serta cara budidayanya lebih mudah daripada cara budidaya lele yang diterapkan sebelumnya. Pembudidaya lele menolak untuk mengadopsi inovasi sistem boster pada saat setelah mengetahui bahwa sistem boster menggunakan kolam yang berbeda dengan sistem konvensional, dan memerlukan biaya yang banyak untuk merubah kolam menjadi kolam central drain.

d. Tahap Implementasi

Pengimplementasian inovasi sistem boster dilakukan sejak tahun 2014. Sistem boster memiliki 3 prinsip yaitu manajemen air, manajemen pakan dan manajemen kesehatan. Walaupun demikian implementasi sistem boster tidak seluruhnya sesuai dengan standar operasional prosedur (SOP) karena ada beberapa hal yang tidak dilakukan seperti pemberian multivitamin/suplemen. Pemberian multivitamin disesuaikan dengan kebutuhan sehingga dapat menekan biaya pengeluaran.

e. Tahap Konfirmasi

Pembudidaya lele memutuskan untuk tetap mengaplikasikan sistem boster karena sudah terbiasa dan sesuai dengan cara kerja sistem tersebut.

Setiap tahapan proses adopsi inovasi menggunakan saluran komunikasi yang berfungsi untuk menyebarluaskan informasi mengenai inovasi sistem boster. Saluran komunikasi yang digunakan adalah komunikasi interpersonal. Komunikasi interpersonal efektif untuk diterapkan pada tahap persuasi, tahap keputusan, tahap implementasi dan tahap kofirmasi, tetapi kurang efektif diterapkan pada tahap pengetahuan karena jangkauannya terlalu sempit.

\section{Saran}

Setiap innovasi yang akan diluncurkan kepada masyarakat haruslah memperhatikan kharakteristik innovasi agar mudah diadopsi selain itu pemilihan saluran komunikasi disesuaikan kharakteristik masyarakat setempat.

\section{DAFTAR PUSTAKA}

Adam L. 2012. Kebijakan Pengembangan Perikanan Berkelanjutan (Studi Kasus: Kabupaten Wakatobi, Provinsi Sulawesi Tenggara dan Kabupaten

154 | Lenny Widjayanthi, Zulfia Asdi Mauladani;Teknologi Sistem Booster... 
Pulau Morotai, Provinsi Maluku Utara. Jurnal Perikanan dan Kelautan

Bachtiar Arifin, Januar Wibowo, Julianto Lemantara. 2017. Rancang Bangun Aplikasi Penjadwalan Dan Perhitungan Biaya Pembesaran Ikan Lele Sistem Boster Pada Farm Fish Boster Centre. Jsika. 6(9):

Ban, A. W. Van Den Dan H.S. Hawkins. 1999. Penyuluhan Pertanian. Yogyakarta: Kanisius.

Bungin, B. 2012. Analisis Data Penelitian Kualitatif Pemahaman Filosofis Dan Metodologis Ke Arah Penguasaan Model Aplikasi. PT Raja Grafindo Persada Everett M. 1983. Diffusion Of Innovations. New York: The Free Press.

Fauzi A. 2005. Kebijakan Perikanan Dan Kelautan (Isu, Sintesis, Dan Gagasan). Jakarta: PT Gramedia Pustaka Utama. Fish Boster Center. 2017. Budidaya Lele Sistem Boster: Aplikatif, Efisien, Dan Profitable.

Frappaolo, C. 2003. Manajemen Pengetahuan. Jakarta: Prestasi Pustaka Publisher Hadi, Moehtar. 2015. Untung Besar Budidaya Lele di Lahan Sempit. Yogyakarta: Araska Publisher.

Hanafi, Abdillah. 1987. Memasyarakatkan Ide-Ide Baru. Surabaya: Usaha Nasional. Http://Www.Fishbostercentre.Com/Home/. [Diakses Pada Tanggal 24 Maret 2018].

Hubeis, Aida Vitayala S. 2017. Komunikasi Inovasi. Buku Materi Pokok Edisi 3 Penerbit Universitas Terbuka.

Hutapea, Yanter, Suparwoto dan Jauhari Efendy. 2013. Kecepatan Adopsi Varietas Unggul dan Kelayakan Usahatani Kedelai di Sumatera Selatan. Agriekonomika. 2(2):

Lori L. Moore. 2012. Characteristics Of Innovations: Lessons Learned From A Statewide Mandatory Implementation Of The Animal Health Network. Journal Of Extension, Sharing Knowledge, Enriching Extension. 50(6):

Mardikanto, Totok. 1993. Penyuluhan Pembangunan Pertanian. Sebelas Maret University Press

Miles, Mattew B, A. Michael Huberman And Johnny Saldana. 2014. Qualitative Data Analysis A Methods Sourcebook. Third Edition: Sage Publications, Inc.

Nasrudin. 2010. Jurus Sukses Beternak Lele Sangkuriang. Jakarta: Pt Penebar Swadaya.

Notoatmodjo, S. 2005. Metodologi Penelitian Kesehatan. Jakarta: Rineka Cipta Rogers.

Putri, Tike Dwi,. Priadi, Dwi Putro,. Sriati. 2014. Dampak Usaha Perikanan Budidaya Terhadap Kondisi Lingkungan dan Sosial Ekonomi 
Masyarakat Pada Lahan Pasang Surut Kabupaten Banyuasin Propinsi Sumatera Selatan. Jurnal Akuakultur Rawa Indonesia. 2(1): 43-54 Saparinto, Cahyo. 2013. Bisnis Ikan Konsumsi Di Lahan Sempit. Jakarta: Penebar Swadaya.

Setiawati. 2016. Faktor-Faktor Yang Mempengaruhi Adopsi Inovasi Teknologi Padi Organik di Desa TelangSari Kecamatan Tanjung Lago, Kabupaten Banyuasin. Jurnal Triagro. 1(1)

Soekartawi. 1988. Prinsip Dasar Komunikasi Pertanian. Jakarta: Penerbit Universitas Indonesia (UI-Press).

Sugiyono. 2015. Metode Penelitian Kuantitatif, Kualitatif, Dan RED. Bandung: Alfabeta.

Susanto, H. 2002. Membuat Kolam Ikan. Jakarta: Penebar Swadaya

Sutrisno. 2007. Budidaya Ikan Air Tawar. Jakarta: Ganeca Exact.

Yusuf, A.M. 2014. Kuantitatif, Kualitatif dan Penelitian Gabungan. Jakarta: Kencana. 